\title{
Sarcoma of the Orbit Pathologic Regional Lymph Nodes TNM Finding v7
}

National Cancer Institute

\section{Source}

National Cancer Institute. Sarcoma of the Orbit Pathologic Regional Lymph Nodes TNM Finding V7. NCI Thesaurus. Code C88817.

A pathologic finding about one or more characteristics of sarcoma of the orbit, following the rules of the TNM AJCC V7 classification system as they pertain to staging of regional lymph nodes. 